\title{
Consanguinity and Birth Defects in the Jerusalem Perinatal Study Cohort
}

\author{
S. Harlap ${ }^{a, b} \quad$ K. Kleinhaus ${ }^{c} \quad$ M.C. Perrin ${ }^{a} \quad$ R. Calderon-Margalit ${ }^{d} \quad$ O. Paltiel ${ }^{d}$ \\ L. Deutsch ${ }^{d}$ O. Manor ${ }^{d}$ E. Tiram ${ }^{d}$ R. Yanetz ${ }^{d}$ Y. Friedlander ${ }^{d}$ \\ ${ }^{a}$ Department of Psychiatry, New York University School of Medicine, Departments of ${ }^{b}$ Epidemiology and

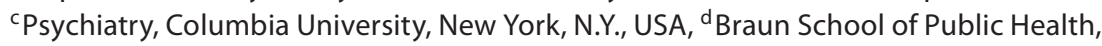 \\ Hebrew University-Hadassah Medical Center, Jerusalem, Israel
}

\section{Key Words \\ Consanguinity $\cdot$ Major birth defects $\cdot$ Uncle-niece $\cdot$ \\ First cousins $\cdot$ Jews $\cdot$ Muslims $\cdot$ Social class}

\begin{abstract}
Background: While parental consanguinity is known to increase the risk of birth defects in offspring, it is hard to quantify this risk in populations where consanguinity is prevalent. Methods: To support ongoing studies of cancer and of psychiatric disease, we studied relationships of consanguinity to 1,053 major birth defects in 29,815 offspring, born in 1964-1976. To adjust for confounding variables (geographic origin, social class and hospital), we constructed logistic regression models, using GEE to take into account correlations between sibs. Odds ratios (ORs) and 95\% confidence limits were estimated in comparison to a reference group of offspring with grandfathers born in different countries. $R \boldsymbol{e}$ sults: With $10.1 \%$ of offspring having consanguineous parents, the adjusted OR for major birth defect was 1.41 (1.12-1.74). Offspring of marriages between uncles-nieces, first cousins and more distant relatives showed adjusted ORs of 2.36 (0.98-5.68), 1.59 (1.22-2.07) and 1.20 (0.89-1.59) respectively. For descendents of grandfathers born in the same country, but not known to be related, the OR was 1.05
\end{abstract}

\section{KARGER \\ Fax +41613061234 \\ E-Mail karger@karger.ch}

www.karger.com (c) 2008 S. Karger AG, Basel 0001-5652/08/0663-0180\$24.50/0

Accessible online at: www.karger.com/hhe
(0.91-1.21); these showed increased risk associated with ancestries in Western Asia (1.27, 1.04-1.55, p < 0.02) or Europe (1.13, 0.79-1.80). Conclusions: A strong association of consanguinity with poverty and low education points to the need to avoid exposure to environmental hazards in these families.

Copyright $\odot 2008$ S. Karger AG, Basel

\section{Introduction}

Marriages between relatives are rare in industrially developed countries and also uncommon in Latin America and Eastern Asia; but they are highly prevalent in most Islamic countries, where, across a broad geographic area from Morocco to Pakistan, $20-80 \%$ of marriages are contracted between relatives [1, 2]. Not only Islam [3], but other religions also allow consanguineous marriages, to various degrees [1]. Migrants from countries where consanguinity is common tend to preserve traditional patterns of marriage, especially if, in their new country, they remain disadvantaged by lower education or lower social class. Even in affluent groups, however, there may be social and economic advantages to marriage between relatives $[1,3]$. 
It is well known that offspring of consanguineous marriages are at increased risk for rare recessive syndromes [4], fetal, infant and child mortality [5-10], birth defects $[5,9,11-20]$ and later disabilities such as deafness [21-23], asthma, mental retardation or epilepsy [24]. Consanguinity may also contribute to more distant outcomes, including some cancers in childhood and younger adults [25-29] and complex diseases in later life [3033].

At the population level, risks may be hard to assess, unless confounding by social and environmental factors can be taken into account. Some studies, in areas where consanguinity is highly prevalent, have suggested that risks of adult diseases may be little affected by consanguinity $[34,35]$. An important limitation is that complex webs of relationships may go back many generations, marriages having been restricted within tribal or minority groups that are sometimes quite small. While marriages between uncle-niece and first cousins lead immediately to coefficients of inbreeding of 0.125 and 0.065 respectively, prolonged inbreeding in earlier generations may cause higher probabilities of identity-by-descent than are predicted by conventional models, even in the absence of known consanguinity in recent generations $[36,37]$. In linkage studies, underestimation of inbreeding coefficients can cause spuriously inflated estimates of linkage. In conventional epidemiologic studies, on the other hand, the risk due to consanguinity may be underestimated if control groups include many distant relatives, or over-estimated if environmental causes of birth defects are not taken into account.

We sought to quantify the risk of major malformations related to different degrees of consanguinity, in the main ethnic groups observed in a historical data base, the Jerusalem Perinatal Study. The data were collected in an era before ultrasound. Our principal aim was to provide a background for our ongoing studies of psychiatric disease and of cancer in the cohort, both in offspring and parents [38]; geographic ancestry is of interest as a risk factor for these outcomes, but may be confounded by consanguinity. More than half of our population descends from Mizrahi and Sephardic Jews with recent origins in Islamic countries; in such Jews, consanguinity is more prevalent than among Ashkenazim [39]. The relevant ancestries are those based in Western Asia (Iraq, Iran, Afghanistan, Turkey, Syria and Lebanon) and North Africa (mainly Morocco). The cohort also includes a small proportion of non-Jews (mainly Palestinian Arabs from rural villages to the west of Jerusalem) who are included for comparison; these are even more highly consanguineous [40].

\section{Methods}

This study is based on a subset of the population-based cohort of families known as the Jerusalem Perinatal Study. During 19641976, all 92,408 births to residents of Western (Israeli) Jerusalem were surveyed. Items abstracted from the birth certificate included demographic information on the parents and both grandfathers; no information was available on grandmothers. These data were supplemented with information abstracted from medical records, interviews and surveillance of pediatric inpatients. The methods and characteristics of the population have been described [38, 41, 42].

During 1965-1968, a subset of mothers ( $\mathrm{n}=11,467$ offspring) were interviewed in antenatal clinics, usually at the first antenatal visit which, in that era, was typically in the fourth month of pregnancy. Interviews were conducted in free neighborhood antenatal clinics and tended not to capture the most affluent women, who chose to use private gynecologists, or those who were known to be at high risk for poor pregnancy outcomes, who were directed to hospital clinics for early antenatal care. The interviews included, inter alia, items on consanguinity, with specific questions probing for any relationship between spouses, types of marriages between uncle-niece and first cousins, and more distant relationships. Reliability was assessed by comparing the responses made in different pregnancies.

Birth defects were ascertained in the Jerusalem Perinatal Study from multiple sources, including labor ward logs, death certificates, surveillance of well-baby clinics and pediatric inpatient admissions; they were coded using ICD-7 [43]. In 1969, each ICD-7 code was classified as a 'major' or 'minor' malformation based on whether the condition would lead to a marked restriction of quality of life, functioning or lifestyle, if uncorrected. 'Major' malformations included inborn errors of metabolism (ICD-7 codes 289.0-289.9), familial hemoglobinopathies and coagulopathies $(292,295,296)$, chromosome abnormalities (308.2), deafmute (397.9), cystic fibrosis (587.2), meconium ileus (587.3), hereditary disorders of bone or growth $(733.4,733.9)$, clubfoot $(748)$, anencephaly (750), spina bifida and meningomelocele (751), hydrocephalus and other malformations of nervous system (752), cataract (753.0), glaucoma (753.1), ptosis (753.2), anophthalmos/ microphthalmos (753.3), other major abnormalities of eye and optic nerve (752.4), other abnormalities of brain or head (753, not including sub-codes assigned to 'minor' defects), heart and great vessels (754), cleft lip and cleft palate (755), tracheo-esophageal fistula and esophageal stricture $(756.0,756.1)$, pyloric stenosis (756.2), exomphalos (756.4), Hirschsprung's disease (756.5), anal atresia and imperforate anus (756.6), biliary atresia (756.8), other major malformations of liver, pancreas and biliary tree (756.9), other major malformations of intestines (756.7), hydronephrosis/ hydroureter (757.0), polycystic kidney (757.1) bladder extrophy (757.2), urethral atresia (757.3), hermaphrodite (757.6), other major genitor-urinary (757.4), dislocation of the hip (758.0), chondrodystrophy (758.1), brittle bones (758.3), lumber spine (758.5) and other vertebrae (758.6), ribs (758.7), polydactyly (758.8), other major bones and joints (758.9 and 758 unspecified), deformities of nose (759.0), larynx (759.1), lung and respiration (759.2), limb reduction deformities (759.8) and other major (759.9). Categories classified as 'minor' included, inter alia, nevi (220), pilonidal cyst (221), hemangiomas (228), telangiectasia (467.1), precocious dentition (533.1), hernias $(560,561)$, minor abnormalities of ear $(753.5$, 
753.6), epi- and hypospadias (757.5), undescended testicle (757.7), other abnormalities of external (757.8) and internal (757.9) genitalia including hydrocele. In the 92,408 offspring, $7.0 \%$ had at least one congenital malformation, with $3.6 \%$ having at least one major defect. The prevalence of the specific defects has been reported for this cohort $[44,45]$ and for different religious communities in Israel [46].

The data base was linked with Israel's Population Registry, most recently in 2005, to verify identities of the offspring, via their unique identity numbers (IDs), and to ascertain and correct those of mothers; then we could link siblings. This study was approved by Institutional Review Boards at the Hadassah Hospital, Jerusalem and Columbia University Medical Center, New York and exempted from the requirement for informed consent.

\section{Data Analysis}

We used SAS ${ }^{\circledR}$ version 9.1 to analyze the data, employing logistic regression to estimate odds ratios for associations between the binary outcome (major birth defect, versus all others) and consanguinity. Covariates were included in the models if they were related to the crude prevalence of both birth defects and consanguinity $(\mathrm{p}<05)$ or if their addition or removal altered, by at least $10 \%$, the estimated odds ratio for birth defects. Unless otherwise stated, all variables were treated as dichotomies, coded as 1 (if present) or 0. Covariates were paternal social class (a six-category ordinal variable based on occupation, varying from 1 (affluent) to 6 (poor)); ethnic (i.e. geographic) origins in Western Asia, based on the birth place of either grandfather; and hospital of birth (representing one small community hospital where birth defects were less prevalent). Other broad categories of ethnic origins included non-Jews versus Jews; and ancestry in North Africa or in Europe, the latter group including the Americas, sub-Saharan Africa and Australia/New Zealand. Other variables tested, but not included in the models, were maternal and paternal ages and levels of education; parents' birth place in Israel, versus immigrants; number of offspring available for study from each family; and whether the offspring was born prior to, or later than, a pregnancy in which the mother was interviewed. Data are presented as odds ratios (ORs), equivalent to relative risks, with $95 \%$ confidence limits. Unless otherwise stated, the reference group was the offspring whose parents were believed to be unrelated and whose grandfathers had been born in different countries. In order to take into account the correlation between siblings, we estimated the confidence limits with generalized estimating equations (GEE), using the GENMOD procedure of SAS ${ }^{\circledR}[47,48]$.

\section{Results}

There were 11,467 offspring born to mothers interviewed in pregnancy in 1965-1968. After excluding 21 interviews lacking responses to questions on consanguinity, there were 9,828 mothers, with 11,446 offspring. Record linkage added 14,052 siblings born earlier and 4,317 born later, giving a cohort of 29,815 offspring. Of the mothers, $14.2 \%$ were interviewed twice, and $0.6 \%$ thrice, in separate pregnancies. Between the first and last interviews of the 1,445 mothers questioned more than once, there was $96 \%$ agreement between the two responses, reporting any kinship between husband and wife (kappa $=0.83,95 \% \mathrm{CI}=0.79-0.88)$. Similarly, general questions regarding marriage between uncle-niece, first cousins and more distant relationships elicited reproducible responses with 98.6, 97.9 and $95.4 \%$ agreement respectively between the two interviews. The 139 women reporting a first cousin relationship in separate interviews gave $87.8 \%$ identical responses in stating whether the husband was related to the wife's mother or her father $(\mathrm{kappa}=83.0,75.4-90.5)$. On the other hand there was less clarity about marriages with more distant relatives; only $79.4 \%$ described the exact relationship in the same way in both interviews (kappa $=0.58,0.45-0.71$ ); because of this we grouped together all types of consanguinity involving relationships more distant than first cousins.

Table 1 shows characteristics of the population with their relationship to various types of kinship and to birth defects. Because paternal and maternal characteristics were similar we show data for only one parent. For offspring with parents thought to be unrelated, the table separates them according to concordance between grandfathers' countries of birth. Not shown in the table, we calculated the proportion of offspring of consanguineous parents who had grandfathers born in the same country. This proportion was greatest $(95.1 \%)$ when the parents were uncle and niece; it decreased from $95.0 \%$ for offspring of first cousins to $87.8 \%$ for more distant relationships. Overall, $91.3 \%$ of offspring whose parents were known to be consanguineous had two grandfathers born in the same country.

Consanguinity was most prevalent in Muslims and in parents born in Islamic countries; it was strongly related to education and occupational social class. The consanguineous couples were slightly more fertile during 19641976 than those who were unrelated, so that although $9.6 \%$ of the mothers reported some degree of kinship with their husbands, $10.1 \%$ of offspring had consanguineous parents. Consanguinity was rare in immigrants from Europe etc, in mothers with higher education, in more affluent fathers, and in younger parents. Major birth defects were most common in offspring of Muslims and immigrants from Western Asia and also varied with education, social class and paternal age.

Table 2 shows the distribution of births in specific types of closely consanguineous marriages, by religion and geographic origin. Uncle-niece marriages were most prevalent in immigrants from North Africa, with most unions involving a wife married to her paternal uncle. Regarding marriages between first cousins, there were 13 offspring 
Table 1. Numbers of births, percent of offspring whose parents were related by various degrees of consanguinity, and numbers and percent with birth defects, by demographic characteristics

\begin{tabular}{|c|c|c|c|c|c|c|c|c|c|}
\hline & \multirow{3}{*}{$\begin{array}{l}\text { Total births } \\
\text { (offspring) } \\
100 \%\end{array}$} & \multicolumn{6}{|c|}{ Offspring whose parents were } & \multicolumn{2}{|c|}{$\begin{array}{l}\text { Offspring with } \\
\text { birth defects }\end{array}$} \\
\hline & & \multicolumn{2}{|c|}{$\begin{array}{l}\text { believed to be unrelated, } \\
\text { two grandfathers from, } \%\end{array}$} & \multicolumn{4}{|c|}{ known to be related, degree of relationship, $\%$} & \multirow[b]{2}{*}{$\mathrm{n}$} & \multirow[b]{2}{*}{$\%$} \\
\hline & & $\begin{array}{l}\text { different } \\
\text { countries }\end{array}$ & $\begin{array}{l}\text { same } \\
\text { country }\end{array}$ & $\begin{array}{l}\text { any known } \\
\text { relationship }\end{array}$ & distant & $\begin{array}{l}\text { first } \\
\text { cousin }\end{array}$ & $\begin{array}{l}\text { uncle- } \\
\text { niece }\end{array}$ & & \\
\hline Total & 29,815 & 43.0 & 46.9 & 10.1 & 5.3 & 4.6 & 0.3 & 1,053 & 3.5 \\
\hline \multicolumn{10}{|l|}{ Religion } \\
\hline Muslim & 310 & 0.3 & 26.5 & 73.2 & 39.4 & 33.9 & 0 & 16 & 5.2 \\
\hline Christian & 50 & 28.0 & 56.0 & 16.0 & 14.0 & 2.0 & 0 & 1 & 2.0 \\
\hline Jewish & 29,455 & 43.5 & 47.1 & 9.5 & 4.9 & 4.3 & 0.3 & 1,036 & 3.5 \\
\hline \multicolumn{10}{|c|}{ Birth place of Jewish mothers } \\
\hline Israel & 10,188 & 63.4 & 32.5 & 4.0 & 2.9 & 1.0 & 0.1 & 352 & 3.5 \\
\hline Other Western Asia & 8,322 & 27.1 & 55.2 & 17.8 & 8.7 & 8.9 & 0.2 & 252 & 4.2 \\
\hline North Africa & 8,233 & 26.3 & 63.3 & 10.4 & 4.8 & 4.9 & 0.6 & 251 & 3.1 \\
\hline Europe etc & 2,699 & 71.0 & 27.7 & 1.3 & 0.7 & 0.7 & 0 & 81 & 3.0 \\
\hline \multicolumn{10}{|c|}{ Education of mother (years) } \\
\hline Unknown & 2,882 & 32.4 & 51.4 & 16.1 & 8.1 & 7.6 & 0.5 & 95 & 3.3 \\
\hline $0-4$ & 4,903 & 16.5 & 65.4 & 18.1 & 8.9 & 8.9 & 0.4 & 225 & 4.6 \\
\hline $5-8$ & 10,036 & 39.3 & 49.7 & 11.1 & 6.0 & 4.8 & 0.3 & 346 & 3.5 \\
\hline $9-12$ & 8,366 & 56.2 & 38.3 & 5.5 & 2.8 & 2.5 & 0.2 & 272 & 3.3 \\
\hline $13+$ & 3,628 & 67.1 & 30.3 & 2.6 & 1.7 & 0.9 & 0.1 & 115 & 3.2 \\
\hline \multicolumn{10}{|c|}{ Social class (occupation of father) } \\
\hline (low) 6 & 6,171 & 23.9 & 60.9 & 15.3 & 7.5 & 7.3 & 0.5 & 253 & 4.1 \\
\hline 5 & 8,212 & 34.6 & 51.5 & 13.9 & 7.3 & 6.2 & 0.3 & 309 & 3.8 \\
\hline 4 & 4,980 & 48.5 & 42.0 & 9.4 & 4.2 & 4.9 & 0.3 & 190 & 3.8 \\
\hline 3 & 3,990 & 54.8 & 39.2 & 6.0 & 3.6 & 2.4 & 0.1 & 134 & 3.4 \\
\hline 2 & 4,586 & 57.6 & 38.6 & 3.8 & 2.7 & 1.0 & 0.2 & 122 & 2.7 \\
\hline (high) 1 & 1,876 & 67.1 & 30.4 & 2.6 & 1.3 & 1.2 & 0.1 & 45 & 2.4 \\
\hline \multicolumn{10}{|l|}{ Age of father } \\
\hline$<25$ & 2,293 & 48.0 & 43.9 & 8.2 & 4.5 & 3.6 & 0.1 & 71 & 3.1 \\
\hline $25-34$ & 16,191 & 46.4 & 44.6 & 9.0 & 4.8 & 4.0 & 0.2 & 560 & 3.5 \\
\hline $35-44$ & 9,533 & 38.5 & 49.6 & 12.0 & 6.0 & 5.6 & 0.4 & 347 & 3.6 \\
\hline $45+$ & 1,621 & 26.3 & 60.8 & 12.9 & 6.9 & 5.5 & 0.6 & 71 & 4.4 \\
\hline \multicolumn{10}{|c|}{ Number of offspring born in 1964-1976 } \\
\hline 1,2 & 6,422 & 48.7 & 42.3 & 9.0 & 4.5 & 4.3 & 0.3 & 208 & 3.2 \\
\hline 3,4 & 13,923 & 45.0 & 45.7 & 9.3 & 5.0 & 4.0 & 0.4 & 495 & 3.6 \\
\hline $5+$ & 9,439 & 36.1 & 51.8 & 12.1 & 6.2 & 5.7 & 0.1 & 350 & 3.7 \\
\hline \multicolumn{10}{|c|}{ Timing of birth in relation to interview } \\
\hline Earlier birth & 14,052 & 43.9 & 46.3 & 9.8 & 5.3 & 4.3 & 0.2 & 468 & 3.3 \\
\hline This pregnancy & 11,446 & 44.3 & 45.9 & 9.9 & 5.0 & 4.5 & 0.3 & 444 & 3.9 \\
\hline Later birth & 4,317 & 36.6 & 51.5 & 11.9 & 5.9 & 5.7 & 0.4 & 141 & 3.3 \\
\hline
\end{tabular}

whose parents were double first cousins; seven were nonJews and six had mothers born in Western Asia so that the sum of the proportions of different types of first cousins add to more than $100 \%$ in these groups. There were significant differences in the distributions of marriages between immediate descendents of brothers and those of sisters, comparing non-Jews with Jews $(\mathrm{p}<0.0001)$. In NonJews, the dominant form of first cousin marriage was between the offspring of brothers, while in Jews, those between the offspring of sisters were more common.

Table 3 shows estimates of the risk of birth defects associated with any consanguinity, and with different degrees of it, with and without adjustment for demographic variables. The $58 \%$ increase in the crude risk of major birth defects in offspring of consanguineous parents was reduced to $39 \%$ by taking into account confounding vari- 
Table 2. Offspring with parents in uncle-niece and first cousin marriages; percent distribution by type of marriage within ethnic groups

\begin{tabular}{|c|c|c|c|c|c|c|}
\hline \multirow[t]{3}{*}{ Type of marriage } & \multicolumn{5}{|c|}{ Ethnic group } & \multirow[t]{3}{*}{ Total } \\
\hline & \multirow{2}{*}{$\begin{array}{l}\text { Non- } \\
\text { Jews }\end{array}$} & \multicolumn{4}{|c|}{ Jewish mothers born in } & \\
\hline & & Israel & West Asia & North Africa & Europe etc. & \\
\hline Uncle/niece, number of births & 0 & 14 & 14 & 53 & 0 & 81 \\
\hline Percent & - & 100.0 & 100.0 & 100.0 & - & 100.0 \\
\hline \multicolumn{7}{|l|}{ Husband is: } \\
\hline Wife's father's brother & - & 50.0 & 64.3 & 83.0 & - & 74.1 \\
\hline Wife's mother's brother & - & 50.0 & 35.7 & 17.0 & - & 25.9 \\
\hline First cousins, number of births & 106 & 103 & 738 & 406 & 18 & 1,371 \\
\hline Percent & 100.0 & 100.0 & 100.0 & 100.0 & 100.0 & 100.0 \\
\hline \multicolumn{7}{|l|}{ Husband is: } \\
\hline Wife's father's brother's son & 59.4 & 10.7 & 30.9 & 19.0 & 38.9 & 28.2 \\
\hline Wife's mother's brother's son & 25.5 & 22.3 & 19.0 & 22.9 & 16.7 & 20.9 \\
\hline Wife's mother's sister's son & 2.9 & 36.9 & 26.8 & 36.5 & 44.4 & 28.8 \\
\hline Wife's father's sister's son & 18.9 & 30.1 & 21.7 & 21.7 & 0.0 & 22.9 \\
\hline
\end{tabular}

Table 3. Numbers of offspring with and without birth defects, unadjusted and adjusted odds ratios (OR) and 95\% confidence interval (CI), by consanguinity and its subgroups

\begin{tabular}{|c|c|c|c|c|c|c|c|c|}
\hline \multirow[t]{2}{*}{ Type of marriage } & \multicolumn{2}{|c|}{ Birth defect(s) } & \multicolumn{3}{|c|}{ Unadjusted } & \multicolumn{3}{|c|}{ Adjusted $^{*}$} \\
\hline & no & yes & OR & $95 \% \mathrm{CI}$ & $\mathrm{p}$ & OR & $95 \% \mathrm{CI}$ & $\mathrm{p}$ \\
\hline \multicolumn{9}{|l|}{ No known consanguinity, grandfathers born } \\
\hline in different countries (reference group) & 12,819 & 408 & 1 & ref & - & 1 & ref & - \\
\hline \multicolumn{9}{|l|}{ No known consanguinity, grandfathers born } \\
\hline in same country & 13,482 & 496 & 1.12 & $0.98-1.28$ & 0.1072 & 1.05 & $0.91-1.21$ & 0.5423 \\
\hline Any known consanguinity & 3,018 & 149 & 1.58 & $1.30-1.93$ & $<0.0001$ & 1.39 & $1.13-1.71$ & 0.0017 \\
\hline \multicolumn{9}{|l|}{ Of these, parents were } \\
\hline Distantly related & 1,502 & 66 & 1.34 & $1.01-1.76$ & 0.0413 & 1.18 & $0.89-1.56$ & 0.2363 \\
\hline First cousins & 1,294 & 77 & 1.81 & $1.40-2.33$ & $<0.0001$ & 1.59 & $1.20-2.04$ & 0.0009 \\
\hline Uncle-niece & 75 & 6 & 2.39 & $1.00-5.70$ & 0.0500 & 2.26 & $0.94-5.45$ & 0.0697 \\
\hline
\end{tabular}

* Adjusted for low paternal social class, mothers born in West Asia and hospital of birth.

ables. The estimates in table 3 use as a reference group the offspring with grandfathers born in different countries. With this reference group, there was a small increase (12\% unadjusted, 9\% adjusted) estimated for the risk of birth defects in offspring whose grandfathers, though not known to be related, were born in the same country. Had we used a wider reference group with both types of grandfathers, crude and adjusted ORs associated with any known consanguinity would have been 1.49 (1.24-1.79, $\mathrm{p}<0.0001)$ and $1.34(1.11-1.62, \mathrm{p}=0.0028)$ respectively.

Regarding degrees of known consanguinity, the ORs were highest, as expected, for offspring of uncle-niece marriages. Not shown in the table, we estimated an adjusted OR of 2.61 (0.97-7.04, based on 5 cases) for offspring of mothers married to paternal uncles and 1.59 (0.26-9.77, 1 case) for those of mothers married to maternal uncles; with overlapping confidence intervals this difference is likely to be due to chance. The table shows a statistically significant $60 \%$ increase in birth defects in offspring of first cousins, and more modest risks associated with more distant degrees of consanguinity.

We questioned whether consanguinity affected the sex ratios of offspring. Results (not tabulated) were likely to be due to chance; proportions of males were 59.3, 52.6, 
Table 4. Numbers of births without and with birth defects, adjusted* odds ratios (OR) and $95 \%$ confidence interval (CI), by ethnic groups and type of consanguinity

\begin{tabular}{|c|c|c|c|c|}
\hline \multirow{3}{*}{$\begin{array}{l}\text { Type of consanguinity } \\
\text { between parents }\end{array}$} & \multicolumn{4}{|c|}{ Ethnic group } \\
\hline & \multirow[t]{2}{*}{ Non-Jews } & \multicolumn{3}{|c|}{ Jews, with mother, father or either grandfather born in } \\
\hline & & West Asia & North Africa & Europe etc. \\
\hline Total births without/with defects & $343 / 17$ & $13,114 / 560$ & $9,325 / 301$ & $7,933 / 220$ \\
\hline \multicolumn{5}{|c|}{ No known consanguinity, grandfathers born in different countries (reference group) } \\
\hline Births without/with defects & & $6,229 / 217$ & $3,371 / 113$ & $6,197 / 170$ \\
\hline $\mathrm{OR}^{*}$ & & 1 & 1 & 1 \\
\hline $95 \%$ CI & & ref & ref & ref \\
\hline $\mathrm{p}$ & & - & - & - \\
\hline \multicolumn{5}{|c|}{ No known consanguinity, grandfathers born in the same country } \\
\hline Births without/with defects & $121 / 4$ & $5,243 / 249$ & $5,111 / 163$ & $1,398 / 43$ \\
\hline $\mathrm{OR}^{*}$ & 1 & 1.27 & 0.84 & 1.13 \\
\hline $95 \% \mathrm{CI}$ & ref & $1.04-1.55$ & $0.64-1.09$ & $0.79-1.60$ \\
\hline $\mathrm{p}$ & - & 0.0169 & - & 0.5049 \\
\hline \multicolumn{5}{|l|}{ Known consanguinity, parents were } \\
\hline \multicolumn{5}{|l|}{ Distantly related } \\
\hline Births without/with defects & $125 / 4$ & $853 / 45$ & $396 / 14$ & $90 / 4$ \\
\hline $\mathrm{OR}^{*}$ & 0.87 & 1.41 & 0.98 & 1.62 \\
\hline $95 \% \mathrm{CI}$ & $0.21-3.67$ & $0.99-2.01$ & $0.57-1.67$ & $0.66-4.01$ \\
\hline $\mathrm{p}$ & 0.8515 & 0.0589 & 0.9328 & 0.2924 \\
\hline \multicolumn{5}{|l|}{ First cousins } \\
\hline Births without/with defects & $97 / 9$ & $769 / 49$ & $402 / 15$ & $25 / 3$ \\
\hline $\mathrm{OR}^{*}$ & 2.38 & 1.69 & 1.03 & 4.29 \\
\hline $95 \%$ CI & $0.72-7.85$ & $1.22-2.34$ & $0.60-1.78$ & $1.06-17.36$ \\
\hline $\mathrm{p}$ & 0.1565 & 0.0017 & 0.9063 & 0.0411 \\
\hline \multicolumn{5}{|l|}{ Uncle-niece } \\
\hline Births without/with defects & $0 / 0$ & $20 / 0$ & $47 / 6$ & $3 / 0$ \\
\hline $\mathrm{OR}^{*}$ & - & - & 3.45 & - \\
\hline $95 \% \mathrm{CI}$ & - & - & $1.50-7.93$ & - \\
\hline $\mathrm{p}$ & - & - & 0.0036 & - \\
\hline
\end{tabular}

* Adjusted for paternal social class and hospital of birth.

50.7 and $51.2 \%$ in the groups of uncle-niece, first cousins, more distant consanguinity and grandfathers from the same country; the overall proportion was $51.1 \%$, after excluding 9 unknowns. Within male and female births, respectively, the ORs for malformations were 2.58 (1.01$6.61, \mathrm{p}=0.0473)$ and $1.95(0.53-7.21)$ associated with uncle-niece parents; $1.53(1.08-2.16, \mathrm{p}=0.0178)$ and 1.77 $(1.22-2.57, \mathrm{p}=0.0025)$ for first cousins; $1.08(0.72-1.61)$ and $1.42(0.98-2.05)$ for distantly related parents; and $1.07(0.88-1.30)$ and $1.11(0.90-1.36)$ for the group whose grandfathers were born in the same country.

Table 4 shows ORs for various degrees of consanguinity, estimated within ethnic groups, defined by the place of birth of any parent or grandfather. For the small group of non-Jews (mainly Arabs), there were too few births for any estimates to be made with certainty and for the reference category we combined the two groups of marriages with no known consanguinity. In Jews from North Africa, uncle-niece marriages were associated with a significantly increased risk of birth defects; but in this ethnic group there was no excess risk associated with other types of consanguineous marriages. In contrast, both the West Asian and European groups showed significantly increased risks of birth defects in offspring of first cousins as well as more modestly increased risks when the parents were more distant relatives or when both grandfathers were from the same country.

Because consanguinity was associated with lower social class we estimated the combined effects of social class and consanguinity on the risk of birth defects (table 5). 
Table 5. Numbers of births without and with birth defects, adjusted* odds ratios (OR) and $95 \%$ confidence interval (CI), by consanguinity and social class

\begin{tabular}{llll}
\hline Relationship between parents & \multicolumn{3}{l}{ Social class of father's occupation } \\
\cline { 2 - 4 } & $1+2$ (high) & $3+4$ (medium) & $5+6$ (low) \\
\hline Total births without/with defects & $6,296 / 167$ & $8,646 / 324$ & $13,821 / 562$ \\
\hline Any consanguinity & & & \\
$\quad$ Births without/with defects & $224 / 9$ & $680 / 31$ & $1,974 / 109$ \\
OR* & 1.56 & 1.62 & 1.93 \\
$95 \%$ CI & $0.66-3.50$ & $1.08-2.43$ & $1.45-2.57$ \\
p & 0.2799 & 0.0195 & $<0.0001$ \\
\hline No known consanguinity, grandfathers from & & & \\
Same country & & & \\
Births without/with defects & $2,280 / 59$ & $3,513 / 142$ & $7,689 / 295$ \\
OR* & 1.01 & 1.48 & 1.37 \\
$95 \%$ CI & $0.72-1.41$ & $1.14-1.94$ & 0.0084 \\
p & 0.9559 & 0.0038 & 4.73 \\
Different countries & & & $4,158 / 158$ \\
Births without/with defects & $3,899 / 99$ & $4,453 / 151$ & 1.29 \\
OR* & 1 & 1.20 & $0.99-1.68$ \\
$95 \%$ CI & ref & $0.92-1.56$ & 0.0621 \\
p & - & 0.1727 & \\
\hline
\end{tabular}

* Adjusted for ethnic group and hospital of birth.

Within subgroups of consanguinity, ORs increased with decreasing social class, and within subgroups of social class, risks of birth defects were increased in association with consanguinity. Although the OR for consanguinity in association with the lowest category of social class was almost twice that of the reference group, i.e. offspring with unrelated parents and grandfathers from different countries, this excess risk was not more than would be expected on the basis of two independent risk factors; thus we conclude that both variables contribute independently to the risk of birth defects.

These conclusions were unchanged in analyses with added adjustment for education, family size, season, year of birth, or ages of parents.

\section{Discussion}

This study confirms the well known association of risk of major birth defects with parental consanguinity, reiterates the knowledge that consanguineous couples tend to be less educated, and provides new information that may aid in the development of prevention programs. As expected, the results show that the closer the degree of consanguinity, the higher the risk. Offspring with ancestries in North Africa show an increased risk for major birth defects if the parents are uncle and niece, as previously reported in this cohort [49] but not at any other level of consanguinity.

Strengths of the Jerusalem Perinatal Study include its relatively large size and the depth of detail available on ethnicity. Information on consanguinity was obtained in a uniform way, using a standard questionnaire; and data on specific forms of close consanguinity proved to be highly reproducible in women interviewed more than once. Findings were not affected by the timing of birth in relation to the questioning of the mother. All births took place in hospitals, or en route, and women delivering were not segregated by social class or ethnic group or religion. More than $91 \%$ of births were in hospitals in which a physician (usually a pediatrician) examined the newborns within a few hours, without knowledge of consanguinity; furthermore, the Jerusalem Perinatal Study's active surveillance of well-baby clinics, pediatric departments and infant death certificates ensured that the detection of birth defects will have been relatively complete. An additional advantage is that it was possible to test for many potential confounders and control for those 
that were important; furthermore, correlation between siblings could be taken into account through use of GEE.

Several limitations must be recognized. There might be undetected sources of confounding and there would certainly be additional relationships within families that would widen the confidence limits, had we been able to account for them. It is frustrating that no information is available on the origins of grandmothers; had such data been available we could have devised a more satisfying control group. Another source of frustration is that few syndromes were recognized in that era and many of the codes available in ICD-7 [43] permit little understanding of specific birth defects; furthermore, one might argue that some of the conditions that were assigned to the ' $\mathrm{mi}$ nor' category would now be assigned as 'major' (e.g. telangiectasia, hypospadias) and vice versa (e.g. hip dislocation). Because of these frustrations, we do not report individual malformations in relation to consanguinity.

Although most of the subjects were Jewish, the data should be broadly generalizable to migrants from other ethnic groups, including immigrants to Europe from Turkey, Pakistan and Arab countries. Furthermore, as is typical of those migrants, more than $98 \%$ of mothers in this study were married and the extreme religious conservatism of the population of Jerusalem makes it very likely that the registered fathers were the biological fathers.

The study reiterates the knowledge that demographic and social variables associated with poverty may contribute to the excess risk associated with consanguinity. This contribution is not trivial. Variant alleles affect vulnerability to hazardous environments and most environmental hazards are assumed to act through such vulnerabilities [50-55]. This study suggests that approximately $30 \%$ of the crude risk associated with consanguinity may be attributable to other variables or to shared effects of poverty and consanguinity. Although variations in social class and education affect the probability of birth defects, our findings should not be interpreted as implying that the risks associated with these variables are completely independent of those associated with consanguinity. These results show consanguinity to be strongly related to lower education, lower occupational social class and childbearing by parents at the extremes of age, as has been shown in other settings $[16,39,56]$. Inbreeding may be associated with cognitive deficits or physical disabilities in the parents that might contribute to downward social mobility, poverty and restriction of choices for work or marriage [57]. More important, new-immigrant 'guest workers' in Europe or their wives, if less educated, may be less aware of risks associated with environmental hazards (e.g. pesticides and other toxic chemicals, smoking or radiation); at the same time, their homes and workplaces may expose them to more of such hazards. They may be less aware of the specific benefits of primary prevention (e.g. with folate supplementation), and may have less access to services for secondary prevention or genetic counseling.

An intriguing finding in North Africans in this study (most are from Morocco) is the lack of risk associated with consanguinity more distant than uncle-niece; however, not too much should be made of this, the differences between North Africans and other Jewish groups being likely to be due to chance. The population of Moroccan Jews is relatively large, and except for some small areas, not considered a genetic isolate. In contrast, the West Asians in this study include several groups drawn from relatively restricted gene pools, including those from Afghanistan, Yemen, Syria, Lebanon, and specific parts of Iran and of India. A further peculiarity of the population of Jerusalem, in contrast to other parts of Israel, is the high concentration of Kurdish Jews among those with origins in Iraq, and to a less extent among those from Turkey, Iran and Syria. Results from this study are consistent with the knowledge that inbreeding in such societies over many generations would lead to high degrees of homozygosity, even in the absence of known consanguinity [36, 37]; the data in table 4 show a significant excess of birth defects in West Asians associated with such (presumed) endogamy, in comparison to the offspring of obviously exogamous marriages.

\section{Acknowledgments}

We thank the offspring and parents in the Jerusalem Perinatal Study.

\section{Competing Interests}

The authors declare that they have no competing interests.

\section{Funding}

Supported by NIH grant 2R01 CA080197 (SH). 


\section{References}

$\checkmark 1$ Bittles AH: Consanguinity and its relevance to clinical genetics. Clin Genet 2001;60:8998.

-2 el-Hazmi MA, al-Swailem AR, Warsy AS, alSwailem AM, Sulaimani R, al-Meshari AA: Consanguinity among the Saudi Arabian population. J Med Genet 1995;32:623-626.

$\checkmark 3$ Albar MA: Ethical considerations in the prevention and management of genetic disorders with special emphasis on religious considerations. Saudi Med J 2002;23:627-632.

4 Chakraborty R, Chakravarti A: On consanguineous marriages and the genetic load. Hum Genet 1977;36:47-54.

5 Stoll C, Alembik Y, Dott B, Feingold J: Parental consanguinity as a cause of increased incidence of birth defects in a study of 131,760 consecutive births. Am J Med Genet 1994;49: 114-117.

-6 Hussain R: The role of consanguinity and inbreeding as a determinant of spontaneous abortion in Karachi, Pakistan. Ann Hum Genet 1998;62:147-157.

-7 Dorsten LE, Hotchkiss L, King TM: The effect of inbreeding on early childhood mortality: Twelve generations of an Amish settlement. Demography 1999;36:263-271.

-8 Khoury SA, Massad DF: Consanguinity, fertility, reproductive wastage, infant mortality and congenital malformations in Jordan. Saudi Med J 2000;21:150-154.

$\checkmark 9$ Mokhtar MM, Abdel-Fattah MM: Consanguinity and advanced maternal age as risk factors for reproductive losses in Alexandria, Egypt. Eur Epidemiol 2001;17:559-565.

10 Zlotogora J, Leventhal A, Amitai Y: The impact of congenital malformations and Mendelian diseases on infant mortality in Israel. Isr Med Assoc J 2003;5:416-418.

-11 Zlotogora J: What is the birth defect risk associated with consanguineous marriages? Am J Med Genet 2002;109:70-71.

12 Magnus P, Berg K, Bjerkedal T: Association of parental consanguinity with decreased birth weight and increased rate of early death and congenital malformations. Clin Genet 1985;28:335-342.

-13 Stoltenberg C, Magnus P, Lie RT, Daltveit AK, Irgens LM: Birth defects and parental consanguinity in Norway. Am J Epidemiol 1997; 145:439-448.

- 14 Rittler M, Liascovich R, Lopez-Camelo J, Castilla EE: Parental consanguinity in specific types of congenital anomalies. Am J Med Genet 2001;102:36-43.

-15 Queisser-Luft A, Stolz G, Wiesel A, Schlaefer $\mathrm{K}$, Spranger J: Malformations in newborn: Results based on 30,940 infants and fetuses from the Mainz congenital birth defect monitoring system (1990-1998). Arch Gynecol Obstetr 2002;266:163-167.
16 Nabulsi MM, Tamim H, Sabbagh M, Obeid MY, Yunis KA, Bitar FF: Parental consanguinity and congenital heart malformations in a developing country. Am J Med Genet 2003;116:342-347.

17 Padmanabhan VT, Sugunan AP, Brahmaputhran CK, Nandini K, Pavithran K: Heritable anomalies among the inhabitants of regions of normal and high background radiation in Kerala: Results of a cohort study, 1988-1994. Int J Health Serv 2004;34:483515.

18 Bromiker R, Glam-Baruch M, Gofin R, Hammerman C, Amitai Y: Association of parental consanguinity with congenital malformations among Arab newborns in Jerusalem. Clin Genet 2004;66:63-66.

19 Madi SA, Al-Naggar RL, Al-Awadi SA, Bastaki LA: Profile of major congenital malformations in neonates in al-Jahra region of Kuwait. Eastern Mediterranean Health J = La revue de sante de la Mediterranee orientale $=$ al-Majallah al-sihhiyah li-sharq almutawassit 2005;11:700-706

20 Sawardekar KP: Profile of major congenital malformations at Nizwa hospital, Oman: 10year review. J Paediatr Child Health 2005;41: 323-330.

21 Al Khabori M: Causes of severe to profound deafness in Omani Paediatr population. Int J Pediatr Otorhinolaryngol 2004;68:13071313.

22 Levi H, Tell L, Cohen T: Sensorineural hearing loss in jewish children born inJerusalem. Int J Pediatr Otorhinolaryngol 2004;68: 1245-1250.

23 Zlotogora J, Carasquillo M, Barges S, Shalev SA, Hujerat Y, Chakravarti A: High incidence of deafness from three frequent connexin 26 mutations in an isolated community. Genet Testing 2006;10:40-43.

24 Bener A, Hussain R: Consanguineous unions and child health in the state of Qatar. Paediatr Perinat Epidemiol 2006;20:372-378.

25 German J, Takebe H: Bloom's syndrome. Xiv. The disorder in Japan. Clin Genet 1989;35: 93-110.

26 Bener A, Denic S, Al-Mazrouei M: Consanguinity and family history of cancer in children with leukemia and lymphomas. Cancer 2001;92:1-6.

27 Chun HH, Gatti RA: Ataxia-telangiectasia, an evolving phenotype. DNA Repair 2004;3: 1187-1196.

28 Gilani GM, Kamal S: Risk factors for breast cancer in Pakistani women aged less than 45 years. Ann Hum Biol 2004;31:398-407.

29 Nijmegen breakage syndrome. The international Nijmegen breakage syndrome study group. Arch Dis Childhood 2000;82:400406.
30 Daghash MH, Bener A, Zirie M, Dabdoub W, Al-Hamaq AO, Al-Arabi ZA: Lipoprotein profile in Arabian type 2 diabetic patients. Relationship to coronary artery diseases. Int J Cardiol 2007.

31 Pasotti M, Repetto A, Tavazzi L, Arbustini E: Genetic predisposition to heart failure. Med Clin North Am 2004;88:1173-1192.

32 Barbari A, Stephan A, Masri M, Karam A, Aoun S, El Nahas J, Bou Khalil J: Consanguinity-associated kidney diseases in Lebanon: An epidemiological study. Mol Immunol 2003;39:1109-1114.

33 Rudan I, Rudan D, Campbell H, Carothers A, Wright A, Smolej-Narancic N, Janicijevic B, Jin L, Chakraborty R, Deka R, Rudan P: Inbreeding and risk of late onset complex disease. J Med Genet 2003;40:925-932.

34 al-Mahroos F, McKeigue PM: High prevalence of diabetes in Bahrainis. Associations with ethnicity and raised plasma cholesterol. Diabetes Care 1998;21:936-942.

35 Jaber L, Shohat T, Rotter JI, Shohat M: Consanguinity and common adult diseases in israeli Arab communities. Am J Med Genet 1997;70:346-348.

36 Leutenegger AL, Prum B, Genin E, Verny C, Lemainque A, Clerget-Darpoux F, Thompson EA: Estimation of the inbreeding coefficient through use of genomic data. Am J Hum Genet 2003;73:516-523.

37 Woods CG, Cox J, Springell K, Hampshire DJ, Mohamed MD, McKibbin M, Stern R, Raymond FL, Sandford R, Malik SS, Karbani G, Ahmed M, Bond J, Clayton D, Inglehearn CF: Quantification of homozygosity in consanguineous individuals with autosomal recessive disease. Am J Hum Genet 2006;78: 889-896.

38 Harlap S, Davies AM, Deutsch L, CalderonMargalit R, Manor O, Paltiel O, Tiram E, Yanetz R, Perrin MC, Terry MB, Malaspina D, Friedlander Y: The Jerusalem perinatal study cohort, 1964-2005: Methods and a review of the main results. Paediatr Perinat Epidemiol 2007;21:256-273

39 Cohen T, Vardi-Saliternik R, Friedlander Y: Consanguinity, intracommunity and intercommunity marriages in a population sample of Israeli jews. Ann Hum Biol 2004;31: 38-48.

40 Zlotogora J: Genetic disorders among Palestinian Arabs: 1. Effects of consanguinity. Am J Med Genet 1997;68:472-475.

41 Davies AM, Prywes R, Tzur B, Weiskopf P, Sterk VV: The Jerusalem perinatal study: 1 . Design and organization of a continuing, community-based, record-linked survey. Isr J Med Sci 1969;5:1095-1106.

42 Harlap S, Davies AM, Grover NB, Prywes R: The Jerusalem perinatal study: The first decade 1964-73. Isr J Med Sci 1977;13:10731091. 
43 WHO: Manual of the International Statistical Classification of Diseases, Injuries and Causes of Death: Seventh Revision. Geneva, World Health Organization, 1957.

44 Harlap S, Davies AM, Haber M, Rossman H, Prywes R, Samueloff N: Congenital malformations in the Jerusalem perinatal study. An overview with special reference to maternal origin. Isr J Med Sci 1971;7:1520-1528.

45 Harlap S, Prywes R, Davies AM: Birth defects and oestrogens and progesterones in pregnancy (letter). Lancet 1975;i:682-683.

-46 Zlotogora J, Haklai Z, Rotem N, Georgi M, Berlovitz I, Leventhal A, Amitai Y: Relative prevalence of malformations at birth among different religious communities in Israel. Am J Med Genet 2003;122:59-62.

47 Liang KY, Zeger SL: Longitudinal data analysis using generalized linear models. Biometrika 1986;73:13-22.
48 Zeger SL, Liang KY: Longitudinal data analysis for discrete and continuous outcomes. Biometrics 1986;42:121-130.

49 Fried K, Davies AM: Some effects on the offspring of uncle-niece marriage in the Moroccan jewish community in Jerusalem. Am J Hum Genet 1974;26:65-72.

50 Ottman R: Gene-environment interaction: Definitions and study designs. Prev Med 1996;25:764-770.

51 Kelada SN, Eaton DL, Wang SS, Rothman NR, Khoury MJ: The role of genetic polymorphisms in environmental health. Environ Health Perspect 2003;111:1055-1064.

52 Yang Q, Khoury MJ: Evolving methods in genetic epidemiology. III. Gene-environment interaction in epidemiologic research. Epidemiol Rev 1997;19:33-43.

53 Kraft P, Hunter D: Integrating epidemiology and genetic association: The challenge of gene-environment interaction. Phil Trans R Soc London 2005;360:1609-1616.
54 Vineis P: A self-fulfilling prophecy: Are we underestimating the role of the environment in gene-environment interaction research? Int J Epidemiol 2004;33:945-946.

55 Vineis P, Kriebel D: Causal models in epidemiology: Past inheritance and genetic future. Environ Health 2006;5:21.

56 Vardi-Saliternik R, Friedlander Y, Cohen T: Consanguinity in a population sample of Israeli muslim Arabs, christian Arabs and druze. Ann Hum Biol 2002;29:422-431.

57 Basel-Vanagaite L, Taub E, Halpern GJ, Drasinover V, Magal N, Davidov B, Zlotogora J, Shohat M: Genetic screening for autosomal recessive nonsyndromic mental retardation in an isolated population in Israel. Eur J Hum Genet 2007;15:250-253. 